\title{
Development of eight-plex microsatellite PCR for parentage control in deer
}

\author{
ATTILA ZSOLNAI ${ }^{1,5}$, ISTVÁN LEHOCZKY², ALICE GYURMÁN³ , JÁNOS NAGY4, LÁSZLÓ \\ SUGÁR ${ }^{1}$, ISTVAN ANTON ${ }^{5}$, PETER HORN ${ }^{1}$ and ISTVÁN MAGYARY ${ }^{1}$

\begin{abstract}
${ }^{1}$ University of Kaposvár, Kaposvár, Hungary, ${ }^{2}$ Research Institute for Fisheries, Aquaculture and Irrigation, Szarvas, Hungary, ${ }^{3}$ Central Agricultural Office, Genetic Laboratory, Research Institute for Agricultural Quality Control, Budapest, Hungary, ${ }^{4}$ Pannon Lovasakadémia, Bőszénfa, Hungary, ${ }^{5}$ Research Institute for Animal Breeding and Nutrition, Herceghalom, Hungary
\end{abstract}

\section{Abstract}

Nine loci have been compiled into two multiplex microsatellite polymerase chain reaction (PCR) sets (four and five loci) and used as a tool to determine the most probable hind for each calf. The two sets were suitable to combine them in an eight-plex reaction. The exclusion probabilities of the eight-plex reaction and the nine loci were 99.3 and $99.6 \%$ respectively, which allows the routine application of eight loci in wildlife management - as a first attempt to use molecular genetic information for such a task and it eliminates multiple sample handling in consecutive PCRs. Two loci out of the nine were never been used in deer previously.

Keywords: parentage, microsatellite, deer

\section{Zusammenfassung}

\section{Entwicklung eines achtfach mulitplexen Microsatelliten PCR Verfahrens zum Abstammungsnachweis beim Hirsch}

Neun Loci wurden in zwei multiplex Microsatelliten Polymerase Kettenreaktion (PCR) Sets (vier und fünf Genorte) kombiniert und genutzt, um die wahrscheinlichste Mutterkuh für jedes Kalb zu bestimmen. Beide Ansätze waren geeignet, um sie in einer achtfach multiplexen Reaktion zu kombinieren. Die Ausschlusswahrscheinlichkeiten der achtfach multiplexen Reaktion der neun Genorte waren jeweils 99,3 und 99,6\%. Dies erlaubt den routinemäßigen Einsatz der acht Genorte in der Wildhege als einen ersten Versuch, molekulargenetische Informationen für eine solche Aufgabe in Ungarn zu nutzen und beseitigt die Notwendigkeit einer mehrfachen Probenhandhabung in fortlaufenden PCRs. Drei der neun Genorte wurden nie zuvor beim Hirsch eingesetzt.

Schlüsselwörter: Abstammung, Microsatellite, Hirsch

\section{Introduction}

Molecular genetic information was already gained successfully in different species e.g. for determination of origin of a modern cattle (BEJA-PEREIRA et al. 2006), for analysis of genetic diversities in donkey (JORDANA et al. 2001) or horse (ABERLE and DISTL 2004) and for classification purposes in pig (ZSOLNAl et al. 2006). 
In deer, comprehensive studies have been conducted in searching for quantitative trait loci (SLATE et al. 2002), and for determination of inbreeding effect on breeding success (SLATE et al. 2000). Molecular data have helped to confirm genetic integrity of Charpatian red deer (FEULNER et al. 2004) and were used to seek for key genes in antler development (MOLNÁR et al. 2007) which might lead to useful markers for breeders.

One aspect of the methodologies is the application of paternity test which is already routinely implemented for example in cattle and sheep (GLOWATZKI-MULLIS et al. 2005, 2007) in many countries. There is an obvious demand from the wildlife managements including deer breeders, to follow-up the lineage, especially when important traits (antler characteristics, body weight, etc.) are logged in the herdbook. Molecular genetic approach has already been implemented for completing this task previously. BONNET et al. (2002) applied eleven microsatellites in 3 multiplex reactions and HAANES et al. (2005) used 25 loci in 6 reactions for genotyping in deer.

The farms sampled in this study are using single mating system, where few stags are in use. Hinds are monitored visually for pregnancy, but after parturition the fate of a calf can not be followed easily by observation, because the calf sometimes chooses other lactating animal than its own mother.

Here we aimed to test and select markers suitable in both fallow and red deer, to incorporate them in one reaction to reduce time and costs in laboratory and to characterise its efficiency in parentage assignment.

\section{Material and methods}

In the summer and fall of 2007, 119 red deers from two farms were selected for parentage analysis. Farm A had 25 hinds including 4 empty ones and 46 calves. Farm B presented 29 hinds including 3 empty ones and 26 calves. Additional 47 fallow-deer samples from two farms were also available. Blood samples were collected into EDTA coated tubes and stored frozen until DNA preparation (Zsolnai et al. 2003). Muscle pieces were stored in Eppendorf tubes under $96 \%$ ethanol on room temperature. Microsatellite loci used for analysis were;

- Set1: BM4208, NVHRT 21, RT 1, NVHRT 73;

- Set2: CSSM066, DIK082, IDVGA59, NVHRT48, OARCP26.

DNA amplification was performed in a Hybaid Thermal Cycler in a total volume of $10 \mu \mathrm{l}$. Parameters of Set1 were: $3 \mathrm{mM} \mathrm{MgCl}, 200 \mu \mathrm{M}$ dNTPs, $0.66 \mathrm{U}$ DyNAzyme, and the corresponding primer pairs in concentration of $0.30,0.15,1.00$ and $1.00 \mathrm{mM}$, respectively (Table 1). PCR conditions included: a denaturation step of 4 min at $94^{\circ} \mathrm{C} ; 30$ cycles of $40 \mathrm{~s}$ at $94^{\circ} \mathrm{C}, 45 \mathrm{~s}$ at $54^{\circ} \mathrm{C}, 45 \mathrm{~s}$ at $72^{\circ} \mathrm{C}$ and a final extension of $10 \mathrm{~min}$ at $72{ }^{\circ} \mathrm{C}$. Parameters of Set2 were: $3.5 \mathrm{mM} \mathrm{MgCl}, 200 \mu \mathrm{M}$ dNTPs, $0.66 \mathrm{U}$ DyNAzyme, and the corresponding primer pairs in concentration of $0.20,0.70,1.20,2.00$ and $0.70 \mathrm{mM}$, respectively (Table 1). PCR conditions included: a denaturation step of 4 min at $94^{\circ} \mathrm{C}, 2$ cycles of $30 \mathrm{~s}$ at $94^{\circ} \mathrm{C}, 30 \mathrm{~s}$ at $58^{\circ} \mathrm{C}, 1 \mathrm{~min}$ at $72^{\circ} \mathrm{C} ; 3$ cycles of $30 \mathrm{~s}$ at $94^{\circ} \mathrm{C}, 30 \mathrm{~s}$ at $57^{\circ} \mathrm{C}, 1 \mathrm{~min}$ at $72^{\circ} \mathrm{C} ; 3$ cycles of $30 \mathrm{~s}$ at $94^{\circ} \mathrm{C}, 30 \mathrm{~s}$ at $56^{\circ} \mathrm{C}, 1 \mathrm{~min}$ at $72^{\circ} \mathrm{C} ; 11 \mathrm{cycles}$ of $30 \mathrm{~s}$ at $94^{\circ} \mathrm{C}, 30 \mathrm{~s}$ at $54^{\circ} \mathrm{C}, 1 \mathrm{~min}$ at $72^{\circ} \mathrm{C}$; 16 cycles of $20 \mathrm{~s}$ at $94^{\circ} \mathrm{C}, 30 \mathrm{~s}$ at $52^{\circ} \mathrm{C}, 1 \mathrm{~min}$ at $72^{\circ} \mathrm{C}$; and a final extension of $10 \mathrm{~min}$ at $72^{\circ} \mathrm{C}$. 
The eight-plex reaction amplifies all loci listed under Set1 and Set2 except OARCP26. Primer concentrations are the same as in Set1 and Set2. $\mathrm{MgCl}_{2}$ concentration is $4.1 \mathrm{mM}$. PCR cycling conditions is the same as for Set2.

Table 1

PCR primers and their concentrations in the Set 1 and Set 2 reactions

$P C R$ Primer und ihre Konzentration in den Reaktionen von Set 1 und Set 2

\begin{tabular}{|c|c|c|c|c|c|}
\hline \multicolumn{2}{|c|}{ Multiplex Locus } & \multirow{2}{*}{$\frac{\mathrm{FL}}{\mathrm{NED}}$} & \multirow{2}{*}{$\begin{array}{c}\mathrm{PC}(\mathrm{mM}) \\
0.15 \\
0.15\end{array}$} & \multirow{2}{*}{$\begin{array}{l}\text { Source } \\
\text { BISHOP et al. } 1994\end{array}$} & \multirow{2}{*}{$\begin{array}{l}\text { Primers } \\
\text { TCA GTA CAC TGG CCA CCA TG } \\
\text { CAC TGC ATG CTT TTC CAA AC }\end{array}$} \\
\hline Set1 & BM4208 & & & & \\
\hline & NVHRT21 & VIC & $\begin{array}{l}0.075 \\
0.075\end{array}$ & RØED and MIDTHJELL 1998 & $\begin{array}{l}\text { GCA GCG GAG AGG AAC AAA AG } \\
\text { GGG GAG GAG CAG GGA AAT C }\end{array}$ \\
\hline & RT1 & PET & $\begin{array}{l}0.50 \\
0.50\end{array}$ & WILSON and STROBECK 1997 & $\begin{array}{l}\text { TGC CTT CTT TCA TCC AAC AA } \\
\text { CAT CTT CCC ATC CTC TTT AC }\end{array}$ \\
\hline & NVHRT73 & 6FAM & $\begin{array}{l}0.50 \\
0.50\end{array}$ & RØED and MIDTHJELL 1998 & $\begin{array}{l}\text { CTT GCC CAT TTA GTG TTTTCT } \\
\text { TGC GTG TCA TTG AAT AGG AG }\end{array}$ \\
\hline \multirow[t]{5}{*}{ Set2 } & CSSM066 & VIC & $\begin{array}{l}0.10 \\
0.10\end{array}$ & MOORE et al. 1994 & $\begin{array}{l}\text { ACA CAA ATC CTT TCT GCC AGC TGA } \\
\text { AAT TTA ATG CAC TGA GGA GCT TGG }\end{array}$ \\
\hline & DIK082 & 6FAM & $\begin{array}{l}0.35 \\
0.35\end{array}$ & HIRANO et al. 1996 & $\begin{array}{l}\text { CCC ACT CTG TCT CCA GTT TG } \\
\text { TAT CCT GAG AAA AGC TGC TAG A }\end{array}$ \\
\hline & IDVGA59 & 6FAM & $\begin{array}{l}0.60 \\
0.60\end{array}$ & MEZZELANI et al. 1995 & $\begin{array}{l}\text { CAG TCC CTC AAC CCT CTT TTC } \\
\text { AAC CCA AAT ATC CAT CAA TAG }\end{array}$ \\
\hline & NVHRT48 & PET & $\begin{array}{l}1.00 \\
1.00\end{array}$ & RØED and MIDTHJELL 1998 & $\begin{array}{l}\text { CGT GAA TCT TAA CCA GGT CT } \\
\text { GGT CAG CTT CAT TTA GAA AC }\end{array}$ \\
\hline & OarCP26 & NED & $\begin{array}{l}0.35 \\
0.35\end{array}$ & EDE et al. 1995 & $\begin{array}{l}\text { GGC CTA ACA GAA TTC AGA TGA TGT TGC } \\
\text { GTC ACC ATA CTG ACG GCT GGT TCC }\end{array}$ \\
\hline
\end{tabular}

FL fluorescent label, PC primer concentrations

Amplified fragments were resolved on ABI310 Automatic Fragment Analyzer. LIZ600 was used as internal standard. Fragment length allocation was accomplished by Genescan and Genotyper programs.

The following softwares were used for data processing and crosschecking the results.: Microsatellite Toolkit (PARK 2001) has been used for data formatting in order to meet the input format of GeneClass (PIRY et al. 2004), WhichRun (BANKS and EICHERT 2000), PAPA (DUCHESNE et al. 2002) and CERVUS (MARSHALL et al. 1998).

\section{Results and discussion}

Altogether 41 microsatellite loci were tested.

Twenty-two of them were checked in simplex reactions using Taq and DyNAzyme polymerases with different PCR conditions. Eight and eleven loci out of the forty-one used by others for parentage tests of sheep (advised by the International Society for Animal Genetics) and bovine (GLOWATZKI-MULLIS et al. 1995), respectively. These sets have also been investigated on deer samples.

Finally nine loci were selected from the 41, which displayed clear electrophoretic patterns on agarose gel or in capillary electrophoretic separation in case of both red and fallowdeer as well. 
Based on the observed lengths of the fragments the primer labelling colours were devised to facilitate multiplexing.

In case of red deer the combined exclusion probabilities for the first parents (CEP) of 4- and 5-plex PCR were 92 and 95\%, respectively. If the two reactions were used consecutively, the previous values were changing to $99.6 \%$ (Table 2). Heterozygozity deficits were observable on most loci (Table 3), but deviation from Hardy-Weinberg equilibrium was significant only in one case (FarmB, locus IDVGA59, data not shown).

Table 2

Characterisation of the multiplex sets used in two farms

Beschreibung der multiplex Sets aus zwei Farmen

\begin{tabular}{lllllll}
\hline & $\begin{array}{l}\text { Farm A } \\
(n=67)\end{array}$ & $\begin{array}{l}\text { Farm B } \\
(n=52)\end{array}$ & $\begin{array}{c}\text { Farm A+B } \\
(n=119)\end{array}$ & $\begin{array}{c}\text { Farm A+B } \\
(n=119)\end{array}$ & $\begin{array}{c}\text { Farm A+B } \\
(n=119)\end{array}$ & $\begin{array}{c}\text { Farm A+B } \\
(n=119)\end{array}$ \\
\hline Locus number & 9 & 9 & 9 & 8 & 5 & 4 \\
Mean $H_{0}$ & 0.6892 & 0.7392 & 0.7121 & 0.6950 & 0.7524 & 0.6618 \\
Mean $H_{e}$ & 0.7790 & 0.7991 & 0.8017 & 0.7979 & 0.08110 & 0.7910 \\
Mean PIC & 0.7466 & 0.7699 & 0.7761 & 0.7738 & 0.7841 & 0.7694 \\
$F_{\text {is }}$ & 0.156 & 0.153 & & & & \\
CnEP (first parent) & 0.0080 & 0.0038 & 0.0037 & 0.0071 & 0.04613 & 0.0777 \\
\hline
\end{tabular}

$n$ number of sampled animals, $H_{0}$ observed heterozigosity, $H_{e}$ expected heterozigosity, PIC polymorphic information content, CnEP combined non-exclusion probability, $F_{\text {is }}$ inbreeding coefficient

Table 3

Observed and expected heterozygosity, number and size range of alleles, $P I C, F_{\text {is }}$ in different loci and farms

Erfasste und erwartete Heterozygotie, Anzahl und Größe der Allele, PIC und $F_{\text {is }}$-Werte bei unterschiedlichen Loci und Farmen

\begin{tabular}{|c|c|c|c|c|c|c|c|c|c|c|c|c|}
\hline \multirow{2}{*}{ Locus } & $H_{0}$ & $H_{e}$ & \multirow[t]{2}{*}{$H_{0}$} & \multirow{2}{*}{$H_{e}$} & \multicolumn{2}{|c|}{ No. of alleles } & \multicolumn{2}{|c|}{ Size range } & \multicolumn{2}{|c|}{ PIC } & \multicolumn{2}{|c|}{$F_{i s}$} \\
\hline & & & & & A & B & A & B & A & B & A & B \\
\hline NVHRT73 & 0.791 & 0.806 & 0.788 & 0.839 & 13 & 17 & $202-234$ & $202-238$ & 0.776 & 0.815 & 0.019 & 0.061 \\
\hline NVHRT21 & 0.500 & 0.799 & 0.596 & 0.854 & 13 & 10 & $142-193$ & $142-168$ & 0.767 & 0.827 & 0.376 & 0.304 \\
\hline BM4208 & 0.687 & 0.860 & 0.615 & 0.866 & 10 & 10 & 144-182 & 144-182 & 0.838 & 0.842 & 0.203 & 0.291 \\
\hline RT1 & 0.642 & 0.654 & 0.635 & 0.566 & 8 & 10 & $208-232$ & $208-232$ & 0.625 & 0.540 & 0.019 & -0.122 \\
\hline DIK82 & 0.627 & 0.767 & 0.769 & 0.849 & 8 & 9 & $122-137$ & $122-137$ & 0.727 & 0.821 & 0.184 & 0.095 \\
\hline IDVGA59 & 0.806 & 0.766 & 0.962 & 0.846 & 12 & 11 & $254-275$ & $254-274$ & 0.728 & 0.822 & -0.053 & -0.139 \\
\hline CSSM66 & 0.657 & 0.756 & 0.750 & 0.760 & 8 & 10 & $161-187$ & $161-187$ & 0.718 & 0.716 & 0.132 & 0.013 \\
\hline CP26 & 0.851 & 0.837 & 0.846 & 0.811 & 10 & 11 & $125-162$ & $123-162$ & 0.809 & 0.778 & -0.017 & -0.044 \\
\hline NVHRT48 & 0.642 & 0.767 & 0.692 & 0.802 & 11 & 10 & $81-107$ & $90-107$ & 0.733 & 0.768 & 0.164 & 0.138 \\
\hline
\end{tabular}

$H_{0}$ observed heterozigosity, $H_{e}$ expected heterozigosity, PIC polymorphic information content, $F_{i s}$ inbreeding coefficient, A, B farm

PAPA, Whichrun, GeneClass and CERVUS programs have been compared for the ability to point on possible hinds. Animals selected as parents by the programs were the same in $93 \%$ of the cases. However the genotype assignment was clear, and repeated PCRs gave the same genotypes, different programs displayed different suggestions for a most probable mother in the remaining cases (7\%). In order to resolve these contradictions, genotypes of the animals in question were aligned and checked visually.

Since the output interpretation was mostly convenient in case of GeneClass and CERVUS, we suggest using them for parentage control if many samples have to be compared. Additionally CERVUS can correct genotyping errors increasing the success of 
paternity assignment (KALINOWSKI et al. 2007) and proved to be useful for forensic applications (CASTAGNASSO et al. 2007).

The two PCR sets are suitable for parentage control in red deer and might be used for other species and farms as well. The combined 8-plex PCR is still retaining high, $99.3 \%$ CEP value for the first parent (Table 3), and can be used alone for the same purpose.

Redesign of primer labelling colours might help in creating the 9-plex PCR, which includes the OaerCP26 locus as well. In this study seven loci are identical with those described in the paper of HAANES et al. (2005), however

- BM4208, NVHRT48 and OarCP26 were used in simplex,

- NVRT73, CSSM066 and NVHRT21 were used in duplex,

- RT1 was used in a triplex reaction by them.

These seven loci were in our initially tested primer-pool and proved to be suitable for multiplexing. The remaining two loci (DIK082, IDVGA59) were developed by independent authors for cattle (Table 1).

In case of fallow-deer (47 animals from two farms), the investigated populations were quite homogeneous, the inbreeding coefficient $\left(F_{i s}\right)$ were 61 and $43 \%$. In these populations more microsatellite loci should be involved for useful parentage test.

The described microsatellite reactions (especially the 8-plex) support the wildlife management's decisions, help to minimise labour and running costs and minimise the possibility of cross contamination or sample swapping. Since there is a chance that the multiplex reaction works on other deer species (BONNET et al. 2002), it might be interesting for the community working in this field.

The gained genotype data

- will be applied to assign lost or strayed individuals to their subpopulation,

- hopefully serve as an essential basis of the efforts of trait mapping,

- helps to select breeding individuals for maintaining diversity in the red deer populations,

- provide basis for the search of populations capable to decrease inbreeding status of the fallow-deer.

\section{Acknowledgements}

This work was supported by national grant no. OMFB-01317/2004.

\section{References}

Aberle KS, Distl 0 (2004) Domestication of the horse: results based on microsatellite and mitochondrial DNA markers. Arch Tierz 47, 517-35

Banks Ma, Eichert W (2000) Whichrun (version 3.2): a computer program for population assignment of individuals based on multilocus genotype data. J Hered 91, 87-9

Beja-Pereira A, Caramelli D, Lalueza-Foxe C, Vernesif C, Ferranda N, Casolih A, Goyache F, Royoi LJ, Contid S, Larid M, Martinij A, Ouraghk L, Magidl A, Atashl A, Zsolnai A, Boscaton P, Triantaphylidiso C, Ploumip K, Sineoq L, Mallegnir F, Taberletb P, Erhardts G (2006) The origin of european cattle: evidence from modern and ancient DNA. Proc Nat Acad Sci USA 103, 8113-8

Bishop MD, Kappes SM, Keele JW, Stone RT, Sunden SL, Hawkins GA, Toldo SS, Fries R, Grosz MD, Yoo J (1994) A genetic linkage map for cattle. Genetics 136, 619-39 
Bonnet A, Thévenon S, Maudet F, Maillard JC (2002) Efficiency of semi-automated fluorescent multiplex PCRs with 11 microsatellite markers for genetic studies of deer populations. Anim Gen 33, 343-50

Castagnasso EE, Kienast ME, García PP, Giovambattista G (2007) A case of multiple assignments (paternity/maternity) in an equine-out breeding system. J Forensic Sci 52, 889-90

Duchesne P, Godbout MH, Bernatchez I (2002) PAPA (package for the analysis of parental allocation): a computer program for simulated and real parental allocation. Mol Ecol Note 2, 191-3

Ede AJ, Pierson CA, Crawford AM (1995) Ovine microsatellites at the OARCP9 OARCP16 OARCP20 OARCP21 OARCP23 and OARCP26 loci. Anim Gen 25, 129-30

Feulner PGD, Bielfeldt W, Zachos FE, Bradvarovic J, Eckert I, Hartl GB (2004) Mitochondrial DNA and microsatellite analyses of the genetic status of the presumed subspecies cervus elaphus montanus (carpathian red deer). Heredity 93, 299-306

Glowatzki-Mullis ML, Gaillard C, Wigger G, Fries R (1995) Microsatellite-based parentage control in cattle Anim Gen 26, 7-12

Glowatzki-Mullis ML, Muntwyler J, Gaillard C (2007) Cost-effective parentage verification with 17-plex PCR for goats and 19-plex PCR for sheep. Anim Gen 38, 86-8

Haanes H, Rosef O, Veiberg V, Røed KH (2005) Microsatellites with variation and heredity applicable to genetic studies of norwegian red deer (cervus elaphus atlanticus). Anim Gen 36, 454-5

Hirano T, Nakane S, Mizoshita K, Yamakuchi H, Inoue-Murayama M, Watanabe T, Barendse W, Sugimoto Y (1996) Characterization of 42 highly polymorphic bovine microsatellite markers. Anim Gen 27, 365-8

Jordana J, Folch P, Aranguren JA (2001) Microsatellite analysis of genetic diversity in the catalonian donkey breed. J Anim Breed Gen 118, 57-63

Kalinowski ST, Taper ML, Marshall TC (2007) Revising how the computer program CERVUS accommodates genotyping error increases success in paternity assignment. Mol Ecol 16, 1099-106

Mezzelani A, Zhang Y, Redaelli L, Castiglioni B, Leone P, Williams JL, Toldo SS, Wigger G, Fries R, Ferretti L (1995) Chromosomal localization and molecular characterization of 53 cosmid-derived bovine microsatellites. Mam Genome 6, 629-35

Marshall TC, Slate J, Kruuk LEB, Pemberton JM (1998) Statistical confidence for likelihood-based paternity inference in natural populations. Mol Ecol 7, 639-55

Maudet C, Miller C, Bassano B, Breitenmoser-Würsten C, Gauthier D, Obexer-Ruff G, Michallet J, Taberlet P, Luikart G (2002) Microsatellite DNA and recent statistical methods in wildlife management: applications in alpine ibex (capra ibex (ibex)). Mol Ecol 11, 421-36

Molnár A, Gyurján I, Korpos E, Borsy A, Stéger V, Buzás Z, Kiss I, Zomborszky Z, Papp P, Deák F, Orosz I (2007) Identification of differentially expressed genes in the developing antler of red deer cervus elaphus. Mol Gen Genom 277, 237-48

Moore SS, Byrne K, Berger KT, Barendse W, McCarthy F, Womack JE, Hetzel DJ (1994) Characterization of 65 bovine microsatellites. Mam Genome 5, 84-90

Park SDE (2001) Trypanotolerance in West African cattle and the population genetic effects of selection. $\mathrm{PhD}$ thesis University of Dublin

Piry S, Alapetite A, Cornuet JM, Paetkau D, Baudouin I, Estoup A (2004) GENECLASS2: a software for genetic assignment and first-generation migrant detection. J Hered 95, 536-9

Pritchard JK, Stephens M, Donelly P (2000) Inference of population structure using multilocus genotype data. Genetics $155,945-59$

Røed KH, Midthjell L (1998) Microsatellites in reindeer rangifer tarandus and their use in other cervids Mol Ecol 7, 1773-8

Slate J, Coltman DW, Goodman SJ, Maclean I, Pemberton JM, Williams JL (1998) Microsatellite loci are highly conserved in red deer (cervus elaphus) sika deer (cervus nippon) and soay sheep (ovis aries) Anim Gen 29, 307-18

Slate Jj, Visscher PM, MacGregor S, Stevens D, Tate ML, Pemberton JM (2002) A genome scan for quantitative trait loci in a wild population of red deer (cervus elaphus). Genetics 162, 1863-73

Slate J, Kruuk LEB, Marshall C, Pemberton JM, Clutton-Brock TH (2000) Inbreeding depression inluences lifetime breeding success in a wild population of red deer (cervus elaphus). Proc Royal Soc Biol Sci 267, 1657-62

Schwarz S, Presuhn U, Kalm E, Reinsch N (2005) Characterizing polymorphism and multiplex feasibility of 142 microsatellite markers from a commercial German landrace line. Arch Tierz 48, 490-3

Thévenon S, Thuy LT, Ly LV, Maudet F, Bonnet A, Jarne P, Maillard JC (2004) Microsatellite analysis of genetic diversity of the vietnamese sika deer (cervus nippon pseudaxis). J Hered 95, 11-8

Wilson GA, Strobeck C, Wu L, Coffin JW (1997) Characterization of microsatellite loci in caribou rangifer tarandus and their use in other artiodactyls. Mol Ecol 6, 697-9 
Zsolnai A, Anton I, Kühn C, Fésüs L (2003) Detection of single nucleotide polymorphisms coding for three ovine prion protein variants by primer extension assay and capillary electrophoresis. Electrophoresis 24, 634-8

Zsolnai A, Radnóczy L, Fésüs L, Anton I (2006) Do mangalica pigs of different colours really belong to different breeds? Arch Tierz 49, 477-83

Received 5 May 2008, accepted 25 January 2009.

Corresponding author:

Dr. ATTILA ZSOLNAI

email: attila.zsolnai@gmail.com

Research Institute for Animal Breeding and Nutrition, Gesztenyés út 1, 2053 Herceghalom, Hungary 